\title{
SWCS CONFERENCE From Dust Bowl to Mud Bowl: Sedimentation, conservation ECHOES measures, and the future of reservoirs
}

\author{
William L. Hargrove, Dewayne Johnson, Don Snethen, and Jan Middendorf
}

T he US government made significant investments in building reservoirs in the 1950s and 1960s, changing much of the rural environment of the United States. The primary authorized use was flood control, but other uses were authorized as well, including irrigation, public water supplies, navigation, hydropower, and recreation. While many of these larger reservoirs were built for a projected life of 150 to 200 years, it is now projected that, for many, that life will be cut short by 50 to 100 years due to sedimentation, nutrient loading, and associated eutrophication. Additionally, over 11,000 smaller flood control reservoirs were designed and constructed with lives of 50 to 100 years by the PL-566 program. For many of these reservoirs, the volume of water storage for public water supplies and other uses has been sharply reduced by sedimentation and accelerated eutrophication, and water quality has been negatively impacted by total suspended solids, nutrients, pesticides, trace metals, and/or endocrine disrupting compounds.

Just as the Dust Bowl of the early 1900s had dramatic social, biological, and physical consequences in the Great Plains of the United States and resulted in dramatic changes in land management, the "Mud Bowl" resulting from the sedimentation and eutrophication of our reservoirs poses a significant threat that also demands corrective action based on sound science and practical affordable technologies. Protecting our reservoirs from sedimentation and accelerated eutrophication is a high-priority issue for many states and for the federal government and is crucial to the future quality of life for our citizens. Since

William L. Hargrove is director of Center for Environmental Resource Management, University of Texas at El Paso, El Paso, Texas. Dewayne Johnson is professional development director at the Soil and Water Conservation Society, Ankeny, lowa. Don Snethen is special projects assistant at the Kansas Center for Agricultural Resources and the Environment, Kansas State University, Manhattan, Kansas. Jan Middendorf is director of Office for Educational Innovation and Evaluation, Kansas State University, Manhattan, Kansas. many of our reservoirs are public water supplies in addition to sources of public recreation, their degradation impacts a variety of economic, public health, environmental, and social concerns.

With core funding from USDA Cooperative State Research, Education, and Extension Service (currently USDA National Institute of Food and Agriculture), the Kansas Water Resources Institute along with the Soil and Water Conservation Society and in collaboration with several other universities and state and federal agencies planned a conference that brought together a group of scientists and water professionals in order to collect the best available scientific knowledge and identify technological solutions that will protect and conserve our federal reservoirs. The conference took place on September 14-16, 2009, in Kansas City, Missouri. It was attended by 172 professionals from 23 states, Washington DC, Puerto Rico, and two Canadian provinces, representing a range of university, government, and private organizations. Through a number of invited and volunteered presentations and a series of brainstorming sessions, as well as drawing on many academic disciplines, the conference evaluated the threats to the sustainability of federal reservoirs, the causative factors behind these threats, the technological solutions and their scientific underpinnings, and the future research needs to improve the sustainability of these vital water resources and the landscapes to which they are connected. This paper summarizes some of the results and findings of the conference. Through this process, we hope to advance interdisciplinary science, research, collaboration, and problem solving for the purpose of addressing a critical national goal-sustaining reservoirs as sources of abundant clean water and recreational opportunities for our citizens.

\section{CURRENT STATUS OF OUR RESERVOIRS AND SOURCES OF SEDIMENT AND NUTRIENTS}

Although upland erosion rates have significantly declined since the mid-20th century, sedimentation from the early part of the century and beyond has significantly shortened the usable lives of many reservoirs (Renwick 2009). For example, a number of reservoirs in the Central Plains have lost storage to sedimentation, ranging from $20 \%$ to $50 \%$ of the original useable storage volume. Bureau of Reclamation storage reservoirs and their dams were designed to accommodate at least the first 100 years of sedimentation without operational problems for outlets or substantial loss of storage capacity (Randle 2009). By the year 2029, a total of 50 of the bureau's 259 reservoirs will be at least 100 years old. About 35\% of Reclamation reservoirs have been surveyed, and according to survey results, about 5.4 million acre-feet of storage capacity has been lost to sedimentation (Randle 2009). The US Army Corps of Engineers operates 396 reservoirs. For twelve of them, sediment has filled between $25 \%$ and $50 \%$ of their volume, and for eight, more than $50 \%$ of their volume has been lost to sediment (Remus 2009).

Sources of sediment include upland erosion, streambanks, and stream channels (Huang 2009; Simon 2009). Soil erosion in agricultural landscapes has generally decreased, especially over the past 50 years, due to implementation of conservation practices. Results from recent assessments in the upper Midwest (Arnold 2009) show that conservation practices have reduced delivery of sediment from farm fields to streams by $65 \%$, nitrogen by $29 \%$, phosphorus by $25 \%$, and atrazine by $28 \%$. In the middle of the last century, total upland erosion was about 2 billion cubic meters per year, compared to less than 1 billion cubic meters per year today. However, this has not translated directly to concomitant decreases in sedimentation due to the fact that much of the sediment from past erosion was deposited in channels and floodplains and is still susceptible to becoming part of stream load under high flow conditions (Trimble 2009). Thus, relatively high sedimentation rates continue in many reservoirs due to continued movement of sediment stored in 
alluvial environments (the "legacy load") and might continue for some unknown period of time (Trimble and Renwick 2009). Reconnaissance research in Iowa, Nebraska, and Tennessee showed that $60 \%-80 \%$ of the observed stream reaches were experiencing significant streambank failure (Simon). These channel erosion processes are primary contributors to sediment loading in streams and sedimentation of reservoirs today, even though the original source of the sediment may be from upland erosion that occurred years or even decades earlier. These sediments also carry nutrients and pesticides from agricultural sources.

Even if sedimentation rates decline, inputs of nutrients are continuing, especially in agricultural watersheds, contributing to accelerated eutrophication (Sharpley 2009). Thus, eutrophication has replaced sedimentation as the dominant water quality problem in many reservoirs. Long residence times for phosphorus will likely prolong this problem (Renwick 2009).

\section{IMPACTS OF SEDIMENTATION AND STRATEGIES FOR REDUCING SEDIMENTATION IN RESERVOIRS}

Sediment loading in streams and sedimentation in reservoirs cause significant environmental damage and result in economic costs. The scientific literature strongly indicates that excessive sediment loading in aquatic ecosystems causes the loss or impairment of fish, macroinvertebrates, and other aquatic organisms (Dzialowski 2009). Pollutants attached to eroded sediments can also be transported, accumulated, and released into surface water bodies, resulting in further impairments (Knight 2009). In reservoirs and lakes, long-term accumulation of sediments can reduce both lake depth and overall volume, contributing to accelerated eutrophication and loss of habitat and biotic carrying capacities that alter sport fishing and other recreational values. Eutrophication also leads to water quality degradation and impairment of uses such as public water supply and recreation (West 2009).

Strategies for addressing sedimentation in reservoirs include the following
(Stark 2009; Hanson 2009; Williams 2009; Howard 2009; Helmers 2009; Garbrecht 2009; Tiessen 2009; Dosskey 2009; Haag 2009; Chesson 2009; and Admire 2009):

- Conservation best management practices on agricultural land

- Streambank stabilization and riparian area protection practices

- Sediment trapping above reservoirs

- Reservoir management

- Dredging to rehabilitate reservoirs

- Decommissioning and/or replacement strategies

- Alternative water collection, holding, and distribution systems

For agricultural cropland and grazing land, there are two types of sediment control practices: conservation structures and management practices. Examples of effective structures include terraces, grassed waterways, vegetative and riparian buffers/filters, grade stabilization structures, and water and sediment control structures. Examples of effective management practices include no-till farming, reduced or minimum tillage farming, farming on the contour, and crop rotations. The most effective system to reduce soil erosion and sediment losses from agricultural fields often involves using a combination of conservation structures and management practices. Some practices reduce soil erosion; others trap sediment in the field, reducing the rate and amount of sediment leaving the field. Some conservation structures can also be applied to grazing lands and/or confined livestock feeding operations.

With proper landscape and riparian management, stream corridor systems can be stabilized, preventing excessive stream bank erosion, down cutting, and entrenchment of the streambed. Stream bank stabilization can be achieved through a variety of techniques, including (1) rock barbs and weirs; (2) stream bank shaping (3) bank revetment using cut trees, rocks, or other materials; (4) live pole plantings; and (5) riparian area restoration and/or protection. Some combination of stream bank stabilization and riparian area restoration and protection is most desirable (Fripp 2009). Common costs range from $\$ 13.00$ to $\$ 30.00$ per linear foot (Williams 2009). Riparian area restoration and pro- tection provides other benefits, such as wildlife habitat, filtering of nutrients and other chemicals before they reach the stream, and carbon sequestration (Dosskey 2009).

A number of structural or reservoir management strategies can be employed to reduce sedimentation in reservoirs. These include (1) building small dams or sediment traps upstream, (2) managing sediment flow and deposition in the reservoir through operational actions, and (3) removing deposited sediment by dredging or excavation (Tiessen 2009; Admire 2009).

For reservoirs that have sustained excessive amounts of sedimentation over the past, dredging represents the most practical method of rehabilitation. However, the cost is great. Values for the cost of dredging range widely from $\$ 2.50$ to $\$ 14.00$ per cubic yard. To put this into context, the cost today for removing sediment from a 7,000 -acre reservoir could be one billion dollars. Disposing of the dredged sediment can also be expensive. Lake sediment can contain trace metals and hazardous chemicals that make disposal problematic. Contaminants of concern include arsenic, chromium, copper, lead, nickel, zinc, cadmium, and mercury. Disposal of dredged sediment and remediation methods for contaminants in dredged sediment include (1) land application, if not contaminated; (2) mixing sediment with biosolids, compost, or manure to make trace elements "unavailable;" (3) phytoremediation of trace elements; and (4) best management practices (BMPs), in terms of rate, timing, and method of application, for nutrient management (Howard 2009).

\section{RESEARCH, EDUCATIONAL, AND POLICY NEEDS}

Through the facilitated brainstorming sessions at the conference, a range of research, educational, and policy needs were identified and prioritized.These are summarized below for each of three broad topic areas: (1) sources and rates of sedimentation, (2) reservoir storage and water quality, and (3) best management practices and watershed management.

Sources and Rates of Sedimentation. One of the biggest research needs is to 
identify and quantify the significant sediment sources and their rates of delivery to reservoirs for a range of ecosystem types and climatic zones. All potential sources need to be considered, including uplands, riparian areas, streambanks, and stream channels. The contribution of ephemeral gullies to upland erosion needs to be quantified. Simulation models need to be developed that account for all the sources of sediment and that predict the impact of management practices. There also is a need to quantify the base sediment load for stable stream channels for a range of physiographic conditions and under conditions of changing climate. With respect to educational needs, professionals need fundamental training in stream morphology and natural stream characteristics and how to accurately identify significant sediment sources and appropriate control measures. Policymakers need to be educated about the original purposes of dams, the benefits of dams, and the benefits of sediment throughput. An adaptive policies framework will be needed to address climate change scenarios for different ecoregions.

Reservoir Storage and Water Quality. There is a need to conduct a more complete assessment of reservoirs in order to better quantify the degree of sedimentation and current rates of sedimentation. In addition, there is a critical need to develop models that (1) simulate how small impoundments affect geomorphology and hydrology of the watershed; (2) evaluate long-term strategies to maintain usable storage over multiple environments; (3) quantify impacts of sedimentation on all parts of the system, utilizing holistic ecosystem approaches; (4) incorporate shifting climate patterns into projections of sediment rate and water supplies; and (5) are coupled with social systems.

A reservoir information system is needed that characterizes the status of reservoirs and documents change over time. This would require a systematic program of selective and recurring reservoir sedimentation surveys. There is a need to improve communications and collaboration among government agencies at different levels (local, state, and federal), so that policies and regulations support rather than counter each other. The public needs to be educated about the condition of reservoirs, their finite life, and the cost of sedimentation and eutrophication. A decision-making process for targeting funds for reservoir management and maintenance is needed.

Best Management Practices and Watershed Management. Research data are needed on BMPs and their impact, including quantifying the lag time between implementing BMPs and in-reservoir changes. We need an improved understanding of watershed scale processes and management, including social aspects of BMP selection and implementation, how to improve flood plain services, how to move sediment downstream, and integrated approaches to controlling sediment load. We need to communicate reasonable expectations for seeing changes and impacts from BMPs and to resolve contradictory goals among different agencies and policy makers. Education of the public on the natural role of the flood plain and the economic benefits of implementing BMPs is needed. Continued development of policies for watershed protection, including easements, zoning, ordinances, and regulations, and programs that reward those who implement practices are needed.

\section{REFERENCES}

Admire, K. 2009. Smaller sediment control structures as a strategy for protecting large reservoirs. Paper presented at the Soil and Water Conservation Society From Dust Bowl to Mud Bowl: Sedimentation, Conservation Measures, and the Future of Reservoirs Conference, Kansas City, MO, September 14-16, 2009.

Arnold, J. 2009. Effects of conservation practices in the Upper Mississippi River Basin - The CEAP national assessment. Paper presented at the Soil and Water Conservation Society From Dust Bowl to Mud Bowl: Sedimentation, Conservation Measures, and the Future of Reservoirs Conference, Kansas City, MO, September 14-16, 2009.

Chesson, B. 2009. Sediment control technologies for urban and suburban landscapes. Paper presented at the Soil and Water Conservation Society From Dust Bowl to Mud Bowl: Sedimentation, Conservation Measures, and the Future of Reservoirs Conference, Kansas City, MO, September 14-16, 2009.

Dosskey, M. 2009. Vegetative buffers and targeting in watersheds. Paper presented at the Soil and Water
Conservation Society From Dust Bowl to Mud Bowl: Sedimentation, Conservation Measures, and the Future of Reservoirs Conference, Kansas City, MO, September 14-16, 2009.

Dzialowski, A. 2009. Impacts of nutrient loading and sedimentation on aquatic life. Paper presented at the Soil and Water Conservation Society From Dust Bowl to Mud Bowl: Sedimentation, Conservation Measures, and the Future of Reservoirs Conference, Kansas City, MO, September 14-16, 2009.

Fripp, J. 2009. Principles of streambank stabilization and stream restoration. Paper presented at the Soil and Water Conservation Society From Dust Bowl to Mud Bowl: Sedimentation, Conservation Measures, and the Future of Reservoirs Conference, Kansas City, MO, September 14-16, 2009.

Garbrecht, J. 2009. Sediment loading and controlling in the grasslands of the Great Plains. Paper presented at the Soil and Water Conservation Society From Dust Bowl to Mud Bowl: Sedimentation, Conservation Measures, and the Future of Reservoirs Conference, Kansas City, MO, September 14-16, 2009.

Haag, D. 2009. Restoring urban watersheds using wetlands and other BMPs. Paper presented at the Soil and Water Conservation Society From Dust Bowl to Mud Bowl: Sedimentation, Conservation Measures, and the Future of Reservoirs Conference, Kansas City, MO, September 14-16, 2009.

Hanson, G. 2009. Small dams safety and/or decommissioning. Paper presented at the Soil and Water Conservation Society From Dust Bowl to Mud Bowl: Sedimentation, Conservation Measures, and the Future of Reservoirs Conference, Kansas City, MO, September 14-16, 2009.

Helmers, M. 2009. Sediment loading and control in crop and livestock agriculture in the Midwest. Paper presented at the Soil and Water Conservation Society From Dust Bowl to Mud Bowl: Sedimentation, Conservation Measures, and the Future of Reservoirs Conference, Kansas City, MO, September 14-16, 2009.

Howard, S. 2009. Major cost and efficacy of dredging. Paper presented at the Soil and Water Conservation Society From Dust Bowl to Mud Bowl: Sedimentation, Conservation Measures, and the Future of Reservoirs Conference, Kansas City, MO, September 14-16, 2009.

Huang, C. Major sources of sediment: Sheet, rill, and ephemeral gully erosion in agricultural landscapes. Paper presented at the Soil and Water Conservation Society From Dust Bowl to Mud Bowl: Sedimentation, Conservation Measures, 
and the Future of Reservoirs Conference, Kansas City, MO, September 14-16, 2009.

Knight, S. 2009. Factors influencing eutrophication in reservoirs. Paper presented at the Soil and Water Conservation Society From Dust Bowl to Mud Bowl: Sedimentation, Conservation Measures, and the Future of Reservoirs Conference, Kansas City, MO, September 14-16, 2009.

Randle, T.J. 2009. Reservoir sedimentation issues. Paper presented at the Soil and Water Conservation Society From Dust Bowl to Mud Bowl: Sedimentation, Conservation Measures, and the Future of Reservoirs Conference, Kansas City, MO, September 14-16, 2009.

Remus, J.I. 2009. Our nation's federal reservoirs: Current status and trends. Paper presented at the Soil and Water Conservation Society From Dust Bowl to Mud Bowl: Sedimentation, Conservation Measures, and the Future of Reservoirs Conference, Kansas City, MO, September 14-16, 2009.

Renwick, W. 2009. The changing role of reservoirs and reservoir sedimentation in the surface waters of the United States. Paper presented at the Soil and Water Conservation Society From Dust Bowl to Mud Bowl: Sedimentation,
Conservation Measures, and the Future of Reservoirs Conference, Kansas City, MO, September 14-16, 2009.

Sharpley, A. 2009. Nutrient loading in streams and eutrophication of reservoirs. Paper presented at the Soil and Water Conservation Society From Dust Bowl to Mud Bowl: Sedimentation, Conservation Measures, and the Future of Reservoirs Conference, Kansas City, MO, September 14-16, 2009.

Simon, A. 2009. Major sources of sediment: Streambanks and channels. Paper presented at the Soil and Water Conservation Society From Dust Bowl to Mud Bowl: Sedimentation, Conservation Measures, and the Future of Reservoirs Conference, Kansas City, MO, September 14-16, 2009.

Stark, K.A. 2009. Management of federal reservoirs for flood control and effects of sedimentation. Paper presented at the Soil and Water Conservation Society From Dust Bowl to Mud Bowl: Sedimentation, Conservation Measures, and the Future of Reservoirs Conference, Kansas City, MO, September 14-16, 2009.

Tiessen, K. 2009. The effectiveness of small dams/ reservoirs on stream quality and quantity in the Canadian prairies. Paper presented at the Soil and Water Conservation Society From Dust Bowl to Mud Bowl: Sedimentation, Conservation Measures, and the Future of Reservoirs Conference, Kansas City, MO, September 14-16, 2009.

Trimble, S.W. 2009. An overview of watershed and reservoir processes. Paper presented at the Soil and Water Conservation Society From Dust Bowl to Mud Bowl: Sedimentation, Conservation Measures, and the Future of Reservoirs Conference, Kansas City, MO, September 14-16, 2009.

West, R. 2009. Taste and odor problems in drinking water supply reservoirs. Paper presented at the Soil and Water Conservation Society From Dust Bowl to Mud Bowl: Sedimentation, Conservation Measures, and the Future of Reservoirs Conference, Kansas City, MO, September 14-16, 2009.

Williams, J. 2009. Economics of streambank stabilization. Paper presented at the Soil and Water Conservation Society From Dust Bowl to Mud Bowl: Sedimentation, Conservation Measures, and the Future of Reservoirs Conference, Kansas City, MO, September 14-16, 2009. 